\title{
Effects of binder type and heat treatment temperature on physical properties of a carbon composite bipolar plate for PEMFCs
}

\author{
Dong-Su Kang and Jea-Seung Roh* \\ School of Advanced Materials and Systems Engineering, Kumoh National Institute of Technology, Gumi 730-701, Korea
}

\section{Article Info}

Received 14 February 2013

Accepted 1 April 2013

*Corresponding Author

E-mail: jsroh@kumoh.ac.kr

\section{Open Access}

DOI: http://dx.doi.org/

10.5714/CL.2013.14.2.110

This is an Open Access article distributed under the terms of the Creative Commons Attribution Non-Commercial License (http://creativecommons.org/licenses/ by-nc/3.0/) which permits unrestricted non-commercial use, distribution, and reproduction in any medium, provided the original work is properly cited.

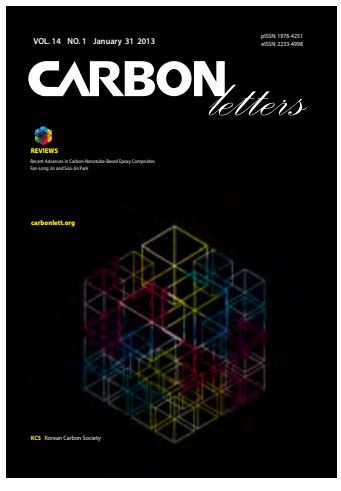

http://carbonlett.org

pISSN: 1976-4251

elSSN: 2233-4998

Copyright $\odot$ Korean Carbon Society

\begin{abstract}
This study investigated a developed process for producing a composite bipolar plate having excellent conductivity by using coal tar pitch and phenol resin as binders. We used a pressing method to prepare a compact of graphite powder mixed with binders. Resistivity of the impregnated compact was observed as heat treatment temperature was increased. It was observed that pore sizes of the GCTP samples increased as the heat treatment temperature increased. There was not a great difference between the flexural strengths of GCTP-IM and CPR-IM as the heat treatment temperature was increased. The resistivity of GPR700-IM, heat treated at $700^{\circ} \mathrm{C}$ using phenolic resin as a binder, was $4829 \mu \Omega \cdot \mathrm{cm}$ which was best value in this study. In addition, it is expected that with the appropriate selection of carbon powder and further optimization of process we can produce a composite bipolar plate which has excellent properties.
\end{abstract}

Key words: polymer electrolyte membrane fuel cell, bipolar plate, graphite, resistivity, flexural strength

\section{Introduction}

For fuel cells to be commercialized, issues of cost and adequate power density must be addressed. If the stack price of polyelectrolyte fuel cells are analyzed by their parts, the catalyst electrode, include Nafion ${ }^{\mathbb{R}}$, accounts for the greatest portion of the cost at $40-50 \%$, followed by the bipolar plate at $20-30 \%$ and the electrolyte and other components at $20-30 \%$ $[1,2]$.

The bipolar plate accounts for over $80 \%$ of the volume and weight of a polyelectrolyte fuel cell stack, and the development of new materials is thus essential to enhance fuel cell volume, weight, and power density. The bipolar plate in fuel cells should have high electrical conductivity and thermal conductivity and high chemical stability, including corrosion resistance. In addition, since it serves as an excellent obturator for refrigerant or gas and supports the stack, it should have high mechanical strength. Along with these various required properties, low manufacturing cost and the ability to be mass-produced are also necessary [3].

Materials for bipolar plate can be broadly classified as graphite, metals, and composite systems. Metal bipolar plates have excellent electrical conductivity and mechanical properties. In addition, their gas transmission properties are outstanding and they can be processed thinly, allowing the reduced weight and miniaturization of fuel cells. However, metal oxides that are generated on the metal surfaces act as electrical insulators and lower the electrical conductivity, and metal cations dissociated from the metal pollute the catalyst layer and polyelectrolytes, and reduce fuel cell performance [4,5].

Graphite bipolar plates are manufactured by impregnating with phenolic and acrylic resin 3-4 times to fill the inner pores and enable a graphite plate to be cut with desirable thickness and 


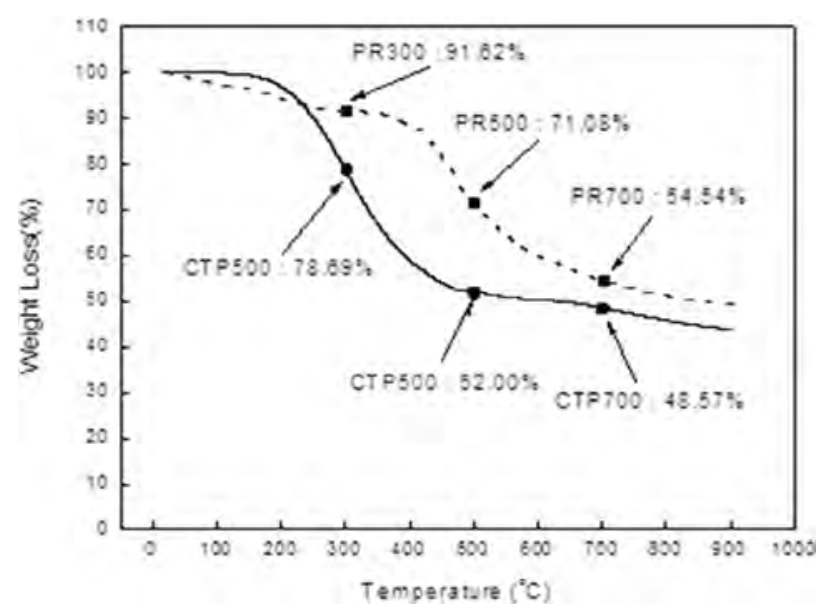

Fig. 1. Result of thermo gravimetric analysis. Yields of binders were different as a function of pyrolysis temperature. CTP: coal tar pitch, PR: phenolic resin.

size. Graphite bipolar plates have excellent electrical conductivity and corrosion resistance, but processing is costly and requires a great deal of time due to milling work, and electrical discharge with gas oil. Mass production is also difficult.

Composite bipolar plates are manufactured by injection molding or molding of mixed conductive materials, carbon, metal powder and organic binder. They afford excellent productivity and chemical stability, but as the content of the binder increases, their electrical properties rapidly decrease $[6,7]$.

This study investigated the development of a process for producing a composite bipolar plate which has excellent conductivity, using coal tar pitch (CTP) and phenolic resin (PR) as binders. We used a pressing method to prepare a compact of graphite powder mixed with binders. Resistivity and flexural strength of the compact was observed. In addition, a plan to enhance the physical properties of the carbon composite bipolar plate was discussed.

\section{Experimental Procedure}

\subsection{Raw materials}

Metallurgical graded coal tar pitch (CTP) and phenolic resin (PR) (from Kangnam Chemical Co.) were used for the binders. Fig. 1 shows the results of thermo gravimetric analysis (TGA, Q500, TA Instrument) of the raw coal used in this study. The TGA measurement was conducted in a nitrogen atmosphere under a heating rate of $10^{\circ} \mathrm{C} / \mathrm{min}$. Yields of binders were different as a function of pyrolysis temperature.

The graphite powder used in this study was synthetic graphite (TIMREX SFG15, Timcal Ltd., Switzerland). Details of the graphite powder properties are provided in Table 1, and an scanning electron microscope (SEM) image is shown in Fig. 2a.

Before it was used in the experiment, solid state raw CTP was ball milled and screened to $-63 \mu \mathrm{m}$ particle size. $16.7 \%$ CTP and PR were respectively added to graphite powder and evenly mixed. Graphite powder and CTP were evenly mixed in the powder phase and kneaded at $150^{\circ} \mathrm{C}$ and subsequently cooled down at room
Table 1. Information of graphite raw powder
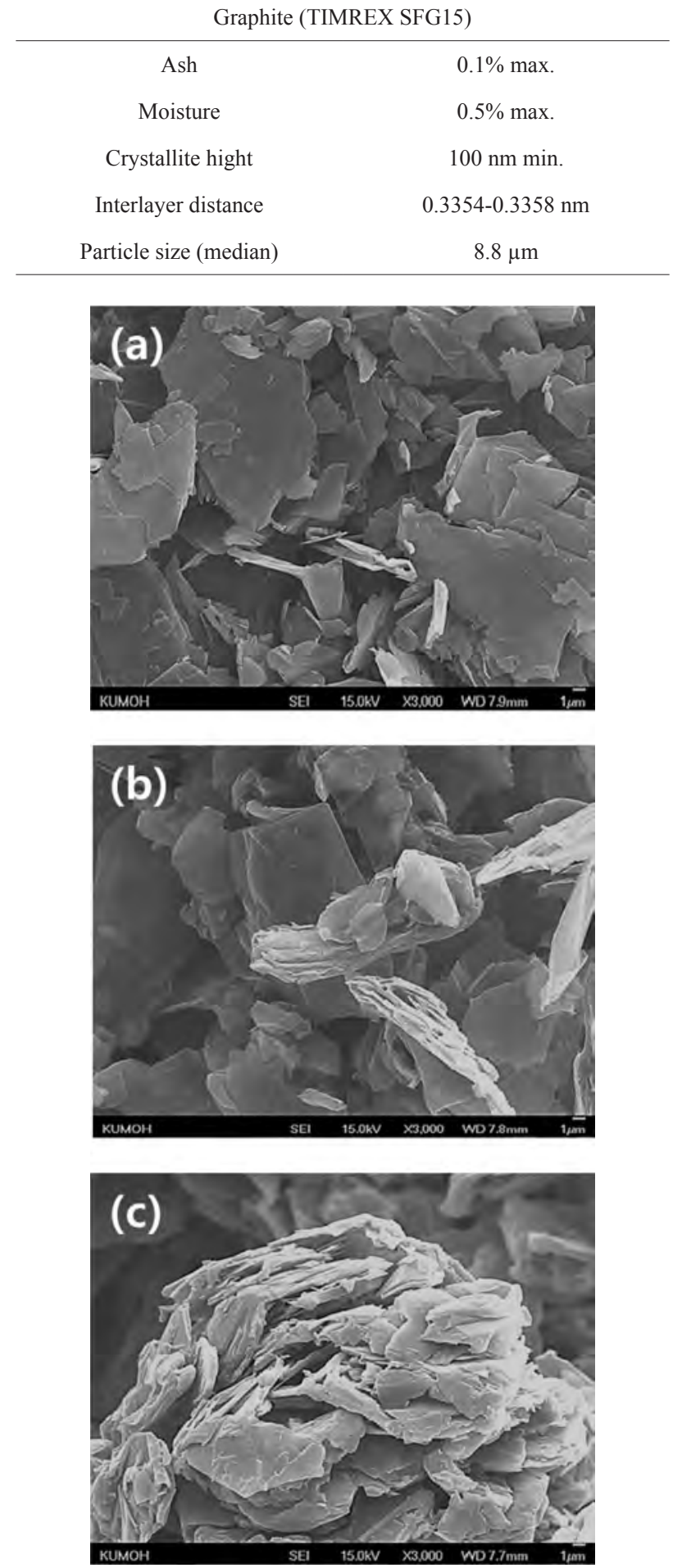

Fig. 2. Scanning electron microscope images of raw graphite powder (a), graphite powder mixed with coal tar pitch (b) and graphite powder mixed with phenolic resin (c)

temperature. PR powder was diluted with ethanol to produce a solution. The graphite powder and PR dilution solution were stirred at room temperature and dried at $80^{\circ} \mathrm{C}$ for $3 \mathrm{~h}$. 
The mixed powders were agglomerated. Then the mixed powders were crushed by a high speed crusher for $1 \mathrm{~min}$ and screened to $212 \mu \mathrm{m}$. Figs. $2 \mathrm{~b}$ and c show SEM images of the graphite powder mixed with CTP, and graphite powder mixed with PR, respectively. We expected that each of the graphite particles would be coated by the binder materials during the kneading processes. However, as shown in Fig. 2b, the graphite flakes and CTP particles (bright particles) separated. Also, as shown in Fig. 2c, PR particles (bright particles) agglomerated with each other.

\subsection{Compacts, heat treatments and impreg- nation}

By uniaxial molding of the screened powder at a pressure of 300 $\mathrm{MPa}$, compacts with a diameter of $20 \mathrm{~mm}$ were manufactured. The compacts (named GCTP and GPR) were subjected to heat treatment at 300,500 , and $700^{\circ} \mathrm{C}$ for $1 \mathrm{~h}$, respectively. Liquid phase epoxy resin was vacuum decompressed up to 0.35 torr to impregnate the heat treated compact. The impregnated compact was inserted into a drying oven and cured at $40^{\circ} \mathrm{C}$ for $1 \mathrm{~h}$ to manufacture final samples. Fig. 3 shows the experimental flow chart of this study.

\subsection{Analysis}

Specimen sizes and apparent densities (ASTM C559:90 (2010)) of the as-formed compacts, heat treated compacts, and

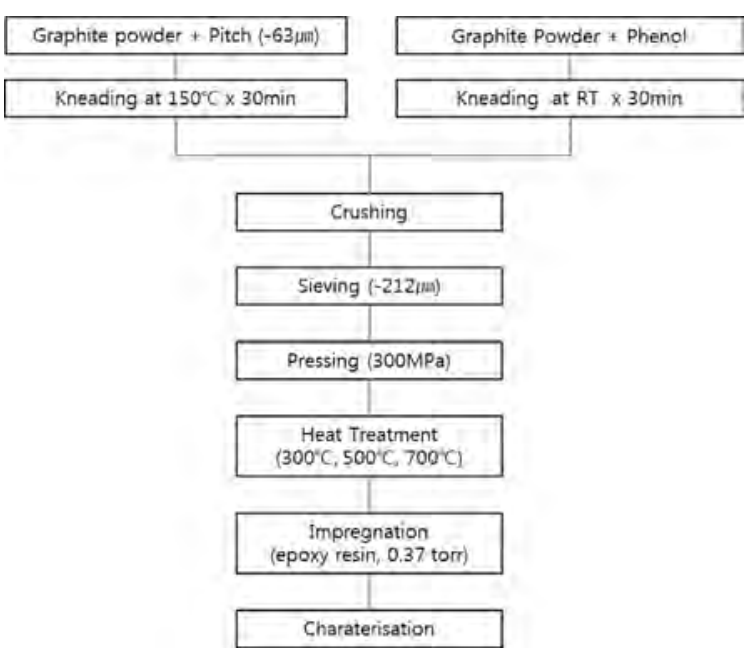

Fig. 3. Experiment procedure.

impregnated heat treated compact specimens were measured. The information for all the manufactured specimens is shown in Table 2.

In addition, resistivity (ASTM C611:98(2010)) and flexural strength (ASTM C651:11) were measured and the microstructure of samples was observed using an optical microscope.

\section{Table 2. Sample name and process conditions}

\begin{tabular}{|c|c|c|c|c|c|c|c|}
\hline Status & Binder & $\begin{array}{l}\text { Temp. } \\
\left({ }^{\circ} \mathrm{C}\right)\end{array}$ & Samples & $\begin{array}{c}\text { Thick (average) } \\
(\mathrm{cm})\end{array}$ & $\begin{array}{l}\text { Dia.. (average) } \\
(\mathrm{cm})\end{array}$ & $\begin{array}{c}\text { Wt.. (average) } \\
\text { (g) }\end{array}$ & $\begin{array}{c}\text { Density (average) } \\
\left(\mathrm{g} / \mathrm{cm}^{3}\right)\end{array}$ \\
\hline \multirow{6}{*}{$\begin{array}{l}\text { Before } \\
\text { HTT }\end{array}$} & \multirow{3}{*}{$\begin{array}{c}\text { CTP } \\
\text { (coal tar pitch) }\end{array}$} & - & & 0.556 & 2.015 & 3.040 & \multirow{3}{*}{1.71} \\
\hline & & - & GCTP & 0.551 & 2.015 & 3.030 & \\
\hline & & - & & 0.553 & 2.015 & 3.040 & \\
\hline & \multirow{3}{*}{$\begin{array}{c}\text { PR } \\
\text { (phenol) }\end{array}$} & - & & 0.547 & 2.010 & 3.010 & \multirow{3}{*}{1.72} \\
\hline & & - & GPR & 0.554 & 2.010 & 3.053 & \\
\hline & & - & & 0.551 & 2.010 & 3.037 & \\
\hline \multirow{6}{*}{$\begin{array}{l}\text { After } \\
\text { HTT }\end{array}$} & \multirow{3}{*}{$\begin{array}{c}\text { CTP } \\
\text { (coal tar pitch) }\end{array}$} & 300 & GCTP300 & 0.622 & 2.077 & 2.957 & 1.57 \\
\hline & & 500 & GCTP500 & 0.623 & 2.078 & 2.837 & 1.51 \\
\hline & & 700 & GCTP700 & 0.619 & 2.075 & 2.840 & 1.51 \\
\hline & \multirow{3}{*}{$\begin{array}{c}\text { PR } \\
\text { (phenol) }\end{array}$} & 300 & GPR300 & 0.583 & 2.047 & 2.953 & 1.61 \\
\hline & & 500 & GPR500 & 0.578 & 2.033 & 2.857 & 1.58 \\
\hline & & 700 & GPR700 & 0.564 & 2.020 & 2.807 & 1.58 \\
\hline \multirow{6}{*}{$\begin{array}{c}\text { After } \\
\text { impregnation }\end{array}$} & \multirow{3}{*}{$\begin{array}{c}\text { CTP } \\
\text { (coal tar pitch) }\end{array}$} & 300 & GCTP300-IM & 0.622 & 2.076 & 3.187 & 1.69 \\
\hline & & 500 & GCTP500-IM & 0.623 & 2.079 & 3.117 & 1.65 \\
\hline & & 700 & GCTP700-IM & 0.619 & 2.074 & 3.157 & 1.68 \\
\hline & \multirow{3}{*}{$\begin{array}{c}\text { PR } \\
\text { (phenol) }\end{array}$} & 300 & GPR300-IM & 0.583 & 2.048 & 3.063 & 1.67 \\
\hline & & 500 & GPR500-IM & 0.578 & 2.035 & 2.957 & 1.64 \\
\hline & & 700 & GPR700-IM & 0.563 & 2.026 & 2.910 & 1.62 \\
\hline
\end{tabular}

GCTP: graded coal tar pitch, GPR: graded phenolic resin. 
Table 3. Result of physical property measurement

\begin{tabular}{|c|c|c|c|c|c|c|}
\hline \multirow{2}{*}{$\begin{array}{l}\text { Samples } \\
\text { Samples }\end{array}$} & \multicolumn{2}{|c|}{ Apparent density $\left(\mathrm{g} / \mathrm{cm}^{3}\right)$} & \multicolumn{2}{|c|}{ Flexural strength (MPa) } & \multicolumn{2}{|c|}{ Electrical resistivity $(\mu \Omega \mathrm{cm})$} \\
\hline & Value & Average & Value & Average & Value & Average \\
\hline \multirow{3}{*}{ GCTP300-IM } & 1.68 & 1.69 & 9.6 & 10.1 & 18362 & 22259 \\
\hline & 170 & 1.69 & 8.2 & 10.1 & 28707 & 22259 \\
\hline & 170 & 1.69 & 12.5 & 10.1 & 19708 & 22259 \\
\hline \multirow{3}{*}{ GCTP500-IM } & 1.65 & 1.65 & 14.9 & 14.3 & 16122 & 12577 \\
\hline & 1.65 & 1.65 & 14.3 & 14.3 & 10923 & 12577 \\
\hline & 1.66 & 1.65 & 13.7 & 14.3 & 10687 & 12577 \\
\hline \multirow{3}{*}{ GCTP700-IM } & 1.68 & 1.68 & 16.8 & 17.1 & 8447 & 6619 \\
\hline & 1.70 & 1.68 & 17.2 & 17.1 & 3479 & 6619 \\
\hline & 1.66 & 1.68 & 17.4 & 17.1 & 7931 & 6619 \\
\hline \multirow{3}{*}{ GPR300-IM } & 1.69 & 1.67 & 19.1 & 20.0 & 19986 & 19552 \\
\hline & 1.70 & 1.67 & 19.6 & 20.0 & 17230 & 19552 \\
\hline & 1.63 & 1.67 & 21.4 & 20.0 & 21439 & 19552 \\
\hline \multirow{3}{*}{ GPR500-IM } & 1.64 & 1.64 & 13.3 & 13.5 & 12173 & 11875 \\
\hline & 1.63 & 1.64 & 12.5 & 13.5 & 11685 & 11875 \\
\hline & 1.64 & 1.64 & 14.7 & 13.5 & 11767 & 11875 \\
\hline \multirow{3}{*}{ GPR700-IM } & 1.63 & 1.62 & 14.6 & 16.9 & 3813 & 4829 \\
\hline & 1.63 & 1.62 & 20.1 & 16.9 & 4328 & 4829 \\
\hline & 1.62 & 1.62 & 15.9 & 16.9 & 6347 & 4829 \\
\hline
\end{tabular}

GCTP: graded coal tar pitch, GPR: graded phenolic resin.

\section{Results and Discussion}

Table 3 shows the result of the physical properties measurements. All measurements were carried out three times with different specimens. The measured value observed for each of the specimens, and their average value, are listed in Table 3.

\subsection{Apparent density}

Fig. 4 shows changes in density as a function of heat treatment temperatures. The density decreased as the temperatures increased, and the decrement of density began to increase remarkably for the impregnated GPR samples (named GPRIM). This is because those specimens underwent partial pyrolysis, and shrank during the heat treatment process, due to the binder properties.

\subsection{Microstructure}

Images of the change of microstructure following the heat treatment of specimens are shown in Fig. 5. It was observed that the pore sizes of GCTP-IM samples increased as the heat treatment temperature increased.

The properties of CTP after liquid pyrolysis, and PR after

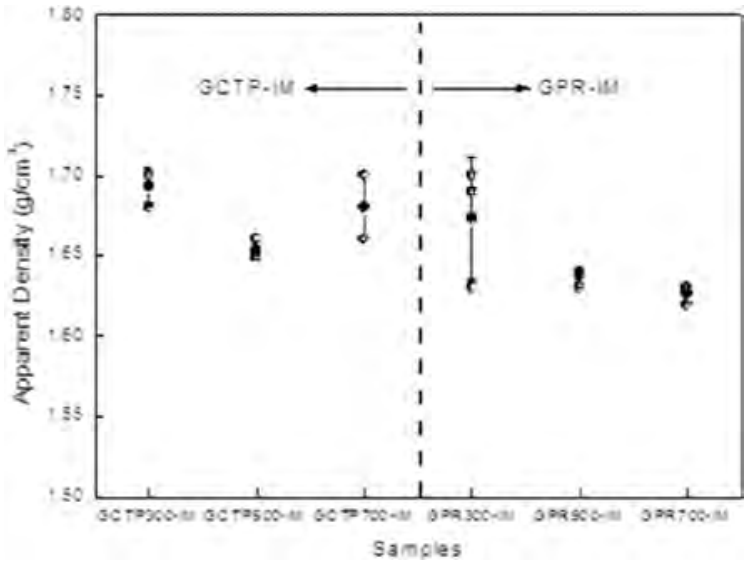

Fig. 4. Result of apparent density measurement. GCTP: graded coal tar pitch, GPR: graded phenolic resin.

solid phase pyrolysis, should be considered. CTP is believed to pass through a liquid phase in the process of carbonization, causing open pores to easily develop. In contrast, PR passing through solid phase pyrolysis leads to the development of closed pores $[8,9]$. Therefore, it is expected that the epoxy resin would easily penetrate through open pores in the GCTP sample. In contrast, a relatively lower weight is expected in the case of the 


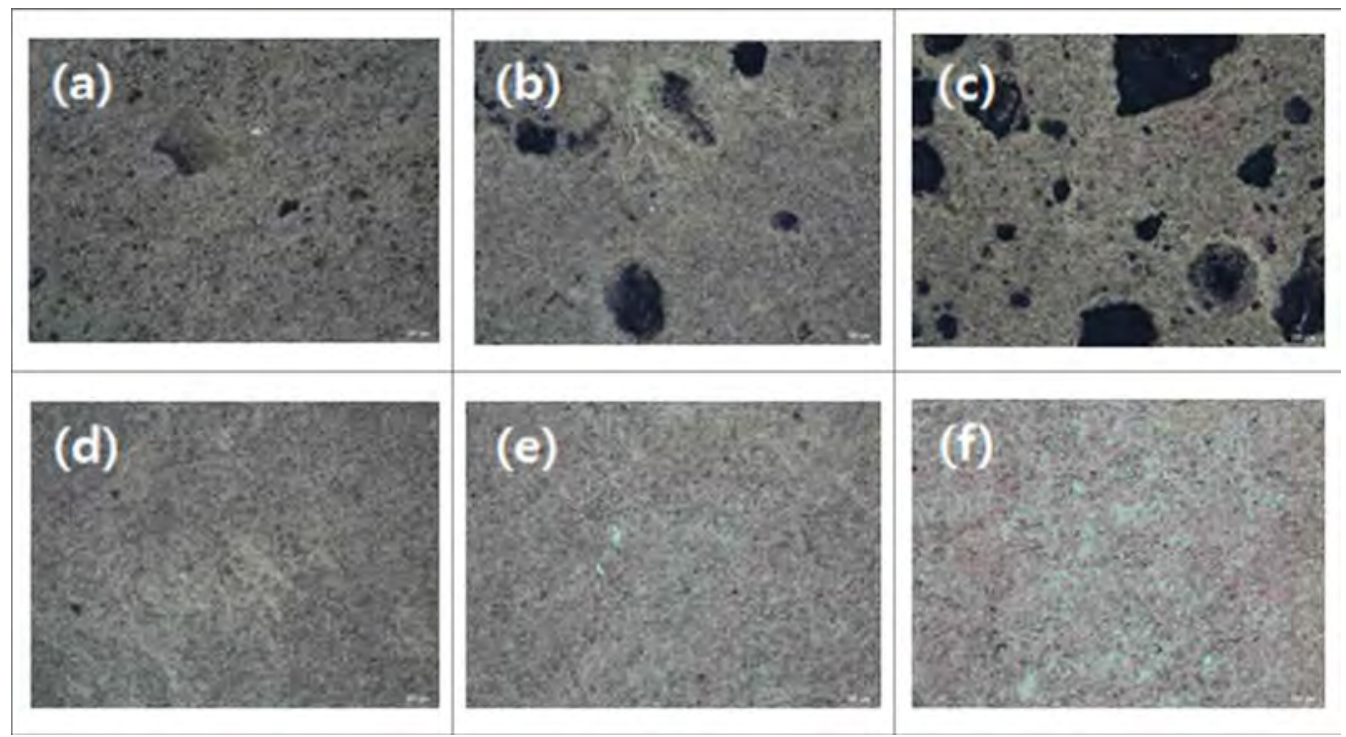

Fig. 5. Optical microscopy images (×100) of GCTP300-IM (a), GCTP500-IM (b), GCTP700-IM (c), GPR300-IM (d), GPR500-IM (e), GPR700-IM (f). GCTP: graded coal tar pitch, GPR: graded phenolic resin.

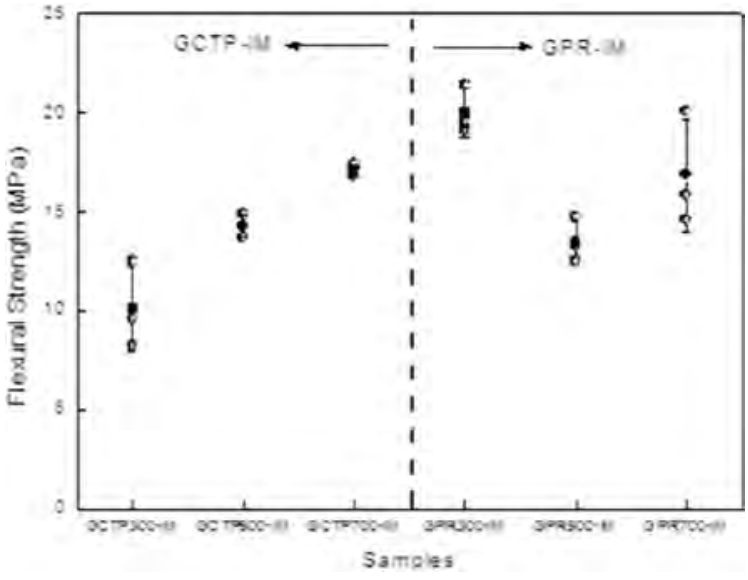

Fig. 6. Result of flexural strength measurement. GCTP: graded coal tar pitch, GPR: graded phenolic resin..

GPR compact since the epoxy resin could not easily penetrate the closed pores.

By measuring the increased weight of the sample after impregnation, shown in Table 2, the amount and degree of impregnated epoxy could be determined. The weights of GCTP300-IM, GCTP500-IM and GCTP700-IM increased by $7.8 \%, 9.9 \%$ and $11.2 \%$ after impregnation, respectively. The rate of increasing weight of GCTP-IM was approximately $2 \%$, and grew with the increase of heat treatment temperature after impregnation with epoxy resin. In contrast, the weight increase rate of GPR-IM was constant (3.5-3.7\%) regardless of the heat treatment temperature after impregnation.

\subsection{Flexural strength}

Fig. 6 presents the results of flexural strength measurement according to heat treatment temperature. GPR300-IM had approximately two times higher flexural strength than

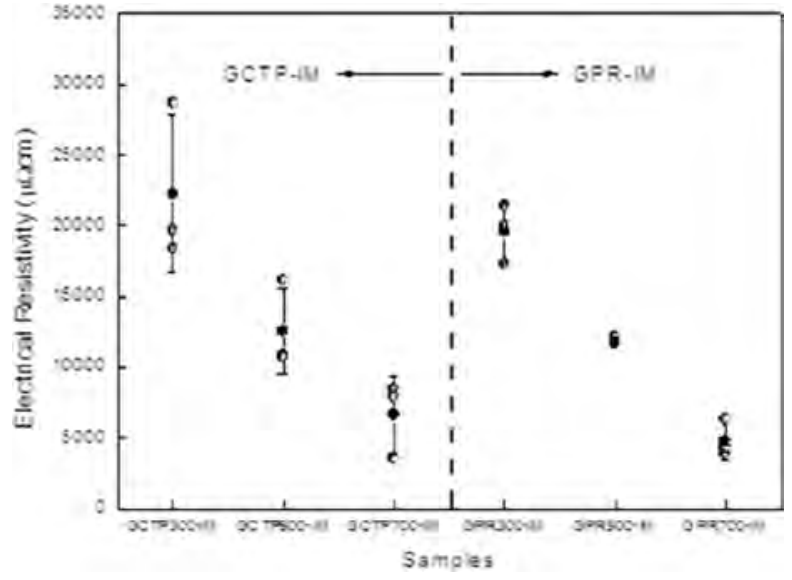

Fig. 7. Result of resistivity measurement. GCTP: graded coal tar pitch GPR: graded phenolic resin.

GCTP300-IM. However, there was not a great difference between the flexural strengths of GCTP-IM and CPR-IM as the heat treatment temperature was increased. During preparation of the sample for measurement of flexural strength, GCTP300-IM was so weak that its edge region detached during the grinding step.

\subsection{Electrical resistivity}

The resistivity measurement results according to heat treatment temperature are shown in Fig. 7. Fig. 7 shows that resistivity decreased with increasing heat treatment temperature, and the resistivity of GPR-IM was lower than that of GCTP-IM. It is believed that the binder materials were converted to carbon structure due to partial carbonization with the increase of heat treatment temperature. Resistivity of the GPR700-IM was measured to be $4829 \mu \Omega \cdot \mathrm{cm}$ which was best value in this study. 
Table 4. Comparison with composite bipolar plates developed other companies

\begin{tabular}{ccccc}
\multicolumn{1}{c}{ Sample } & & Apparent density $\left(\mathrm{g} / \mathrm{cm}^{3}\right)$ & Flexural strength $(\mathrm{MPa})$ & Electrical resistivity $(\mu \Omega \cdot \mathrm{cm})$ \\
\hline & GCTP300-IM & 1.69 & 10.1 & 22259 \\
This study & GCTP500-IM & 1.65 & 14.3 & 12577 \\
& GCTP700-IM & 1.68 & 17.1 & 6619 \\
& GPR300-IM & 1.67 & 20.0 & 19552 \\
& GPR500-IM & 1.64 & 13.5 & 11875 \\
\hline \multirow{2}{*}{ Reference } & GPR-700-IM & 1.62 & 16.9 & 4829 \\
& SLBP 9 & 1.91 & 31.9 & 8974 \\
\hline
\end{tabular}

GCTP: graded coal tar pitch, GPR: graded phenolic resin.

\subsection{Comparison between other results}

Table 4 presents the results of an analysis comparing the research results of this study to composite bipolar plates developed by others. The subjects of the comparative analysis were SLBP9, a product developed by Seunglim Carbon Metal Co., Ltd. via uniaxial molding by mixing carbon filler and resin, and a commercial material (FU4369) produced by Schunk of Germany [10]. Generally, when producing a carbon molded bipolar plate, the natural graphite and binder contents are kept constant at $65 \mathrm{vol} \%$ and $25 \mathrm{vol} \%$, respectively. Reinforcing materials such as carbon fiber are then added for the remaining 10 vol\% [11].

The SLBP9 and FU4369 show higher density and strength than our specimen's value. However the resistivity of GPR700IM of this study was $4829 \mu \Omega \cdot \mathrm{cm}$ which was the best value in Table 4.

\subsection{Future works}

We can evaluate the results of this study. The electrical property of the bipolar plate was improved through the heat treatment of binder materials. However the density and strength should be improved for bipolar plate application.

Therefore some processes, such as the pre-treatment of raw materials and impregnation method, should be modified for future works. We suggest two ways to improve the density and strength. First, the size of the raw graphite particle should be increased. At the beginning of this study we expected the binder materials would be pasted onto the filler particles. However the mixed powders were agglomerated. In addition, pre-treatment of the binder materials should be carried out, to allow the filler particles to be easily coated on, and to form open pores in the specimen body. Second, the vacuum impregnation method should be changed to a pressure impregnation process. The epoxy resin could not penetrate into the specimens with the vacuum impregnation method.

We expect that the properties can be improved through these modified processes, and we can develop the process to produce a composite bipolar plate which has excellent properties.

\section{Conclusions}

This study investigated the development of a process for producing a composite bipolar plate which has excellent conductivity by using CTP and PR as binders. We used a pressing method to prepare a compact of graphite powder mixed with binders. The resistivity and strength of the impregnated compact was observed to be as follows.

It was observed that pore sizes of the GCTP samples increased as the heat treatment temperature increased. There was not a great difference between the flexural strengths of GCTP-IM and CPR-IM as the heat treatment temperature was increased.

From a comparison of the proposed plate with composite bipolar plates developed by other researchers, the density and strength of our result were not good. The resistivity of GPR700IM was $4829 \mu \Omega \cdot \mathrm{cm}$ which was best value in this study.

In addition, it is expected that with the appropriate selection of carbon powder and optimization of process we can develop a process to produce a composite bipolar plate which has excellent properties.

\section{Acknowledgments}

This paper was supported by Research Fund, Kumoh National Institute of Technology.

\section{References}

[1] Bar-On I, Kirchain R, Roth R. Technical cost analysis for PEM fuel cells. J Power Sources, 109, 71 (2002). http://dx.doi.org/10.1016/ S0378-7753(02)00062-9.

[2] Costamagna P, Srinivasan S. Quantum jumps in the PEMFC science and technology from the 1960s to the year 2000: Part I. Fundamental scientific aspects. J Power Sources, 102, 242 (2001). http://dx.doi.org/10.1016/S0378-7753(01)00807-2.

[3] Kim JH. Commercializing technology development of bipolar plates for polymer electrolyte membrane fuel cell. Trans Korean Hydrog New Energy Soc, 22, 409 (2011). 
[4] Hwang IU, Yu HN, Kim SS, Lee DG, Suh JD, Lee SH, Ahn BK, Kim $\mathrm{SH}$, Lim TW. Bipolar plate made of carbon fiber epoxy composite for polymer electrolyte membrane fuel cells. J Power Sources, 184, 90 (2008). http://dx.doi.org/10.1016/j.jpowsour.2008.05.088.

[5] Cho EA, Jeon US, Hong SA, Oh IH, Kang SG. Performance of a $1 \mathrm{~kW}$-class PEMFC stack using TiN-coated 316 stainless steel bipolar plates. J Power Sources, 142, 177 (2005). http://dx.doi. org/10.1016/j.jpowsour.2004.10.032.

[6] Hung Y, El-Khatib KM, Tawfik H. Testing and evaluation of aluminum coated bipolar plates of pem fuel cells operating at $70^{\circ} \mathrm{C}$. J Power Sources, 163, 509 (2006). http://dx.doi.org/10.1016/j.jpowsour.2006.09.013.

[7] Cho EA, Jeon US, Ha HY, Hong SA, Oh IH. Characteristics of composite bipolar plates for polymer electrolyte membrane fuel cells. J
Power Sources, 125, 178 (2004). http://dx.doi.org/10.1016/j.jpowsour.2003.08.039.

[8] Yamashita Y, Ouchi K. A study on carbonization of phenol-formaldehyde resin labelled with deuterium and 13C. Carbon, 19, 89 (1981). http://dx.doi.org/10.1016/0008-6223(81)90112-3.

[9] Walker PL, Jr., Thrower PA. Chem Phys Carbon, 9, 173 (1973).

[10] Kwon YK, Lee JK, Ji D, Lee JY. Electrochemical characteristics of home-made bipolar plate and its relationship with fuel cell performance. J Korean Electrochem Soc, 12, 68 (2009).

[11] Maheshwari PH, Mathur RB, Dhami TL. Fabrication of high strength and a low weight composite bipolar plate for fuel cell applications. J Power Sources, 173, 394 (2007). http://dx.doi. org/10.1016/j.jpowsour.2007.04.049. 